\title{
2. Uncovered fields in the research literature
}

\subsection{Neglected secret writings in secrecy studies}

Secrecy as a historical phenomenon has received increasing scholarly attention in recent decades. The communication of secrets and the secret ways of communication, keeping diplomatic, scientific or technological information secret, hiding private or sexual information, and strategies of learning about the secrets of others have increasingly been regarded as crucial not only in large-scale societies, communities, and religions of the past, but also in smaller units such as professions, spiritual sects, and families.

This relevance is reflected in a number of recent publications. William Eamon has surveyed the wide variety of genres and topics in the literature of secrecy in late medieval and early modern Europe, and has demonstrated that books of secrets played an essential role in history of science. Edited by Agostino Paravicini-Bagliani, a thematic volume of the Micrologus Series collected several topics of and approaches to medieval secrecy ranging from theological mysteries to magical arcana and political secrets, ${ }^{2}$ while another volume, edited by William Newman and Anthony Grafton, concentrated more on the notion of the occult in early modern alchemy and astrology. ${ }^{3}$ A German collection of essays gave an even wider picture, and included such historical themes as diplomatic secrecy, sexual secrecy, intimacy, and the place of secrets in art. ${ }^{4}$ Karma Lochrie's Covert Operations concentrates on women's secrets, gossips, confessions, and sexuality - an area where secrecy overlaps with intimacy. ${ }^{5}$ Tanya Luhrmann studied the psychological, social, or sometimes even healing effects of initiation into secret mysteries in rites of contemporary groups of magic, trying to

1 William Eamon, Science and the Secrets of Nature: Books of Secrets in Medieval and Early Modern Culture (Princeton: Princeton University Press, 1994).

2 Il Segreto / The Secret, ed. A. Paravacini Bagliani, Micrologus, vol. XIV (Florence: Sismel, 2006).

3 William Newman and Anthony Grafton, eds. Secrets of Nature: Astrology and Alchemy in Early Modern Europe (Cambridge, MA: The MIT Press, 2001).

4 Gisela Engel, Brita Rang, Klaus Reichert and Heide Wunder, eds. Das Geheimnis am Beginn der europäischen Moderne (Frankfurt am Main, Klostermann, 2002).

5 Karma Lochrie, Covert Operations: The Medieval Uses of Secrecy (Philadelphia: University of Pennsylvania Press, 1999). 
discover how the act of sharing a secret becomes a tool of group formation and group cohesion. ${ }^{6}$

Pamela Long juxtaposed the openness of mining treatises with the secrecy of alchemical writings while exploring the role of authorship in the history of technology in an age when the notion of intellectual property had to be reinterpreted. ${ }^{7}$ One of the many merits of her analysis is that she makes an effort to define the notions of secrecy and openness appropriately. Going back to the fundamental work of the philosopher Sissela Bok from $1982,{ }^{8}$ Long defines secrecy as "intentional concealment", and distinguishes it, first of all, from privacy and secondly from the unknown, such as the secrets of nature. ${ }^{9}$

Walking in Long's footsteps, Koen Vermeir makes the relationship of secrecy and openness more explicit. By conducting a concept analysis as well as providing historical examples, he argues that the two concepts are not necessarily negating one another, and therefore they cannot be defined as each other's opposites. He claims that both secrecy and openness are categories with a range: things are not either completely secret or absolutely public - they are partly hidden to certain groups, while being partially public for another audience. ${ }^{10}$ (This argument is not entirely novel. As early as 1970 John Cohen wrote that the secrecy of a given information is not an absolute feature; rather, it should be seen as a scale measuring how carefully one hides information, what risks one takes to keep it secret, and what obstacles anyone who wants to uncover this secret might face. As Cohen mentions, secrecy can only be defined in relation to a community with which one wishes to share the secret information. $)^{\text {11 }}$

Vermeir goes on to emphasize that "secret as content" and "secrecy as action" do not necessarily coincide, however close these two categories may seem to be at first sight. Many handbooks - both historical and contemporary - that contain "secrets" that only a selected audience is supposed to know are in fact widely publicized (secret without secrecy), while the secrets of some esoteric circles seem banal or empty once they are uncovered

6 Tanya Luhrman, "The magic of secrecy," Ethos 17 (1989): 131-165.

7 Pamela O. Long, Openness, Secrecy, Authorship: Technical Arts and the Culture of Knowledge from Antiquity to the Renaissance (Baltimore: Johns Hopkins University Press, 2001).

8 Sissela Bok, Secrets: On the Ethics of Concealment and Revelation (New York: Vintage, 1989.)

9 Long, Openness 1-15.

10 Koen Vermeir, "Openness versus secrecy? Historical and historiographical remarks." The British Journal for the History of Science, 45 (2012): 165-188.

11 John Cohen, Homo Psychologicus (London: George Allen and Unwin Ltd, 1970), 133-138. 
(secrecy without a secret). The rhetoric of secrecy is a recurring feature of early modern science - several kinds of knowledge had the exciting trademark of secrecy that in effect could easily be obtained by any literate person. Similarly, advocacy of the value of "publicity" in the seventeenth century did not mean actual publicity - as it does not mean it today, either. Many writers argued in the past and argue today that open access to information is a value, when the reality is that, because of the special customs of publication, or because of intentional secrecy, these writers' knowledge is not widely accessible at all. ${ }^{12}$

The overview of the history of secrecy should be closed by mentioning two monumental undertakings. The first is Sigila, a French-Portuguese journal completely devoted to a 'transdisciplinary' study of secret. It publishes short studies, essays, works of literature and visual art, it reviews publications on the topic of secret and lists conferences and presentations that are relevant in the field. The thematic editions since 1998 cover the topics of forgetting, confession, secret symbols, code names, dissimulation, feminine secrets, music, intimacy, orientalism, shame, silence, nighttime, secret languages, guardians of secret, and in the 2005 issue (no. 15) the relationship of secret and science. ${ }^{13}$ The other major work is the three-volume monumental multi-authored overview edited by Aleida and Jan Assmann that is less historically oriented, and devotes more attention to literature and cultural history; nonetheless, it marks a growing interest in the field of secrecy by leading contemporary scholars. ${ }^{14}$ Both undertakings are fine exx amples of the growing need on the part of contemporary leading researchers to unfold the concepts of secret.

The list can easily be continued to include many more publications on secret, ${ }^{15}$ dealing with its different aspects. William Eamon, the first importt ant voice on the topic, writes that in 1982 his first conference lecture on secret books was received with vague looks, from 2000 on, however, one conference has been organized after the other on the early modern history of secret - one of these was precisely that workshop in Cambridge in 2008,

12 Vermeir, op. cit. and Pamela O. Long, "The Openness of Knowledge: An Ideal and its Context in 16th-Century Writings on Mining and Metallurgy," Technology and Culture 32 (1991): 318-355.

13 Sigila, publication semestrielle transdisciplinaire consacrée à l'analyse de la figure du secret, 1998-.

14 Aleida Assmann and Jan Assmann, eds. Geheimnis und Öffentlichkeit (Schleier und Schwelle I, Munich: Fink, 1997); Geheimnis und Offenbarung (Schleier und Schwelle II, Munich: Fink, 1998); Geheimnis und Neugierde (Schleier und Schwelle III, Munich: Fink, 1999).

15 Among others: Philippe Dujardin, ed. Le Secret (Lyon, Presses Universitaires de Lyon, 1987) 
where he made this observation when presenting his views on the future research directions of secret books. ${ }^{16}$

The secondary literature, just like the topic itself, is rather rich. Authors make a serious attempt at contextualizing the phenomenon of secret by reconstructing the social background, aspects and consequences of secrecy. A common characteristic of them, however, is that they rarely mention a major means of secrecy, that is, secret writing (cryptography and code breaking), and when they do, they concentrate on its application in the political domain and on its technological evolution. The neglect of cryptography in secrecy studies is fairly surprising; one cannot but agree with Dejanirah Couto, who argued in her article on early modern espionage in the Ottoman Empire, that "without cryptography, secrecy lacks material form or readability". ${ }^{17}$ The context of secret writings is secrecy, and the conn text of studying them should be the literature of secrecy.

\subsection{Secrecy in the history of science}

The contrasting concepts of secrecy/openness are much discussed in historiography of science. Robert Merton's four well-known scientific norms - universalism, communalism, disinterestedness, and organized skepticism - have had a long-lasting influence on how researchers approached the issue. ${ }^{18}$ One of the norms, communalism is particularly relee vant here. According to this norm, scientific achievements should be made freely available to anyone, since knowledge is the common intellectual property of society, not of the individual. Merton, of course, was fully aware that his norms do not necessarily describe the reality of scientific research. He looked at them as the ethos of scientific research, a set of values that would guarantee the free and effective progress of science, and one that academic institutions of democratic societies strive to achieve in an ideal world. In historiography, however, the norms were taken up in a somewhat simplified way. Researchers simply accepted the view that openness is a

16 William Eamon, "How to Read a Book of Secrets" in Elaine Leong és Alisha Rankin, eds. Secrets and Knowledge in Medicine and Science 1500-180o (Surray: Ashgate, 2011), 23-46, particularly: 39.

17 Dejanirah Couto, "Spying in the Ottoman Empire: Sixteenth-Century Encrypted Correspondence," in Francisco Bethencourt and Florike Egmond, eds. Cultural Exchange in Early Modern Europe (Volume III) - Correspondence and Cultural Exchange in Europe, 1400-1700 (Cambridge: Cambridge University Press, 2007) 274-312, particularly: 278.

18 Robert Merton, "Science and technology in a democratic order," Journal of Legal and Political Sociology 1 (1942): $115^{-126 .}$ 
positive value that supports academic research, and that secrecy, which is more characteristic of the history of technology, was fortunately abandoned by modern science. Science, on this understanding, has become open, whereas technology remained secretive. ${ }^{19}$

This view was, of course, challenged both in regard to the past and the present of the scientific practice. John Ziman pointed out that Merton's norms are constantly being violated in the twentieth century, and these violations are somewhat natural in the so-called post-academic phase of science. ${ }^{20}$ Since corporations are taking the place of national academic inn stitutions in financing scientific research, they exert a growing influence on the object of research along with the degree of its publicity. In the meantime, historians examining early modern science and technology realized that retaining, hiding, or restrictedly sharing information had a much greater and more constructive importance in science and craft industry than previous authors had believed. ${ }^{21}$

A recent thematic issue of The British Journal of the History of Science illustrates vividly how historiographical research has moved from the conventional and unreflective view that contrasted openness and secrecy, mapping this pair of opposites onto another one, that of science and technology. ${ }^{22}$ Editors Koen Vermeir and Dániel Margócsy argue that the focus of the research on secrecy has been narrowed down too much to the very topic of secrets themselves, when in fact practices of secrecy would be a more fruitful object of investigation. As Georg Simmel put it, in what is perhaps the first systematic analysis of the social role of secrecy, it functions as the principle of social hierarchy: "Secrecy gives the person enshrouded by it an exceptional position; it works as a stimulus of purely social derivation, which is in principle quite independent of its casual content."23

19 David Hull, "Openness and secrecy in science: their origins and limitationsm," Science, Technology and Human Values 10 (1985): 4-13; Ernan McMullin, "Openness and secrecy in science: some notes on early history," Science, Technology and Human Values 10 (1985): 14-23.

20 John M. Ziman, "Postacademic Science: Constructing Knowledge with Networks and Norms," Science Studies 9 (1996): 67-80.

21 See Koen Vermeir and Dániel Margócsy, "States of secrecy: an introduction." The British Journal for the History of Science, 45 (2012): 153-164; Karel Davids, "Craft Secrecy in Europe in the Early Modern Period: A Comparative View," Early Science and Medicine, 10 (No. 3, Openness and Secrecy in Early Modern Science) (2005): 341-348; Stephan R. Epstein, "Craft Guilds, Apprenticeship, and Technological Change in Preindustrial Europe," The Journal of Economic History $5^{8}$ (1998): 684-713. 22 The British Journal for the History of Science 45 (2012), Special Issue: States of Secrecy. Editors: Koen Vermeir and Dániel Margócsy.

23 Georg Simmel, "The sociology of secrecy and of secret societies," American Journal of Sociology 11 (1906): 441-498, particularly: 464 and 478. 
Vermeir and Margócsy regard secrecy in science as more than a tool for protecting knowledge from intellectual competitors: in their view it is a dynamic social practice, a self-maintaining force that creates and organizes a group, establishes and manages hierarchy within it, and fundamentally influences the mechanisms of exclusion-inclusion. Often, the content of the secret is not really relevant in the study of the dynamics of secrecy; the ability to withhold or share information in itself becomes a power enabling social control, regardless of the object of secret. ${ }^{24}$

Simmel, Vermeir and Margócsy and the authors they cite unanimously share such observations that help make sense of the seemingly unexplainable secrecy practices in early modern Hungary. Presently, however, I would like to point out that the history of secret writings is the neglected stepchild of not only the research of secrecy in general, but specifically of the history of scientific secrecy. The use of cryptography and scientific secrecy of some seventeenth-century figures such as Galileo Galilei, John Wilkins, Robert Hooke, Christian Huygens, John Wallis, Giambattista Della Porta, ${ }^{25}$ or Robert Boyle ${ }^{26}$ have been studied to some extent. The close relationship of mathematics and decoding has also been analyzed. ${ }^{27}$ With the exception of a few remarkk able yet sporadic studies, however, little effort has been made to include the use of secret writings into the careful and socially sensitive analyses of historiography.

This is illustrated by the third volume of The Cambridge History of Science. ${ }^{28}$ Focusing on early modern science, this volume offers an excellent perspective on the present state of contemporary research, as it is reflected in its outstanding group of authors (Katharine Park, Lorraine Daston, Steven Shapin, William Eamon, Peter Dear, Anthony Grafton, Paula Findlen, William Newman, Brian Copenhaver, etc.) as well as in the topics it covers (among many others: the meaning of experiment, evidence and persuasion, and the old and new scenes of science, such as: markets, squares and towns, libraries, schoolrooms, botanical gardens, anatomical theaters, laboratories

\footnotetext{
24 Vermeir and Margócsy, "States of secrecy."

25 Kristie Macrakis, "Confessing secrets: secret communication and the origins of modern science," Intelligence and National Security 25 (2010): 183-197; Mario Biagioli, "From ciphers to confidentiality: Secrecy, Openness and Priority in Science," The British Journal for the History of Science, 45 (2012), 213-233.

26 See the publications of Lawrence M. Principe, e.g.: "Robert Boyle's Alchemical Secrecy: Codes, Ciphers and Concealments," Ambix 39 (1992): 63-74.

27 Peter Pesic, "Secrets, Symbols, and Systems: Parallels between Cryptanalysis and Algebra, 1580-1700," Isis 88 (1997): 674-692.

28 Katharine Park and Lorraine Daston eds. The Cambridge History of Science, Volume 3, Early Modern Science (Cambridge, Cambridge University Press, 2006.)
} 
and coffee houses.) Secret and secrecy are recurrent themes of the volume, yet cryptography is only mentioned once, and even there it is somewhat mixed into the history of constructed languages. ${ }^{29}$ All this is rather surpriss ing in light of the fact that the first golden era of cryptography coincides with the early modern period. Besides the publications of Macrakis, Biagioli and Principe, the above-mentioned publication on the 2008 Cambridge conference provides a more refreshing example..$^{30}$ Secret writings are menn tioned in relation with the alchemic diaries of Boyle, and with a collection of medical formulas compiled for Eleanor, the daughter of Sir Peter Temple. ${ }^{31}$ The questions addressed on both occasions are particularly relevant for our present interest: what the reason for using encryption really was (why did Temple encode formulas that were publicly available at the time in a printed form), who was meant to be excluded from the communication, how cryptographic secrecy helped define and limit a community, and, finally, how ciphers appeared in areas remote from the practice of diplomacy such as a research journal and a compilation of private recipes. If only for the length of a few pages, this publication does integrate the practice of cryptography into the framework of secrecy research.

In spite of these exceptions, one may draw the conclusion: the social history of cryptography and the integration of secret writings into the practices of secrecy do not seem particularly relevant for the most progressive movement of contemporary history of science.

\subsection{The need for social history in cryptography studies}

Thus far, there has been little success in finding cryptography in the literature on secrecy. It is worthwhile now to look at the same issue from another angle, and see how secrecy appears in the studies on ciphers. Cryptography has been the subject of considerable secondary literature in recent decades. The beginning of the twentieth century marks the birth of two richly documented volumes of Aloys Meister, ${ }^{32}$ who studied the European beginnings

29 Mary Baine Campbell, "Literature," in Park and Daston, Early Modern Science, 756-772, cryptography appears: 762 .

30 Elaine Leong and Alisha Rankin, eds. Secrets and Knowledge in Medicine and Science 1500-1800 (Surray: Ashgate, 2011).

$31 \quad$ Ibid. 9-10, 100-101.

32 Aloys Meister,Die Anfänge dermodernen diplomatischen Geheimschrift (Paderborn:Ferdinand Schöningh, 1902); idem, Die Geheimschrift im Dienste der päpstlichen Kurie von ihren Anfängen bis zum Ende des 16. Jahrhunderts (Paderborn: Ferdinand Schöningh, 1906). 
of the history of ciphers, more specifically the diplomatic cryptography of Italian cities and the papal court in the late medieval and early modern periods. He reconstructed several hundred code keys in these volumes and published a number of crucial cryptographic treatises.

Though several useful articles, sources and monographs were published in the previousand following decades on Italian, ${ }^{33}$ Spanish ${ }^{34}$ French, ${ }^{35} \mathrm{German}^{36}$ and Polish ${ }^{37}$ ciphers, one can say without exaggeration that the history of cryptography as a discipline was born as late as in 1967 , when the Codebreakers, a lengthy monograph by David Kahn was published. ${ }^{38}$

Kahn, relying on the information available at the time, carried out a systematic investigation on the history of ciphers from the beginnings to WWII. The primary focus of his research was the twentieth century. Though the story of Enigma was not incorporated into the book as it was still classified at the time, Kahn was a pioneer in publishing many details of other areas. Despite the emphasis on modern times, his review on the early modern era is a highly rich and useful introduction even today.

Kahn's oeuvre was fundamental in establishing the field of cryptography: he was a co-founder of Cryptologia, the journal on the history of cryptology that has published studies and reviews related to the history of cryptography since $1977 \cdot^{39} \mathrm{Kahn}$ is also a prominent figure of the great biannual

33 Luigi Pasini, "Delle scritture in cifra usate dalla Repubblica Veneta," in Il Regio Archivio Generale di Venezia, (Venezia: Pietro Naratovich, 1873). 291-328; Bartolommeo Cecchetti, "Le scritture occulte nella diplomazia veneziana," Atti del Regio Istituto Veneto 14 (1868-69): 1186-1211.

34 J. P. Devos, Les chiffres de Philippe II (1555-1598) et du Despacho Universal durant le XVIIe siècle (Brussels: Académie Royale de Belgique, 1950); Henry Biaudet, "Un chiffre diplomatique du XVIe siècle: Étude sur le cod. Nunz. Polonia 27. A. des archives secretes du Sant-Siège," Annales Academiae Scientiarum Fennice (Helsinki: 1910); Pierre Speziali, "Aspects de la cryptographie au XVI siècle," Bibliothèque d'humanisme et Renaissance 17 (1955): 188-206.

35 J. P. Devos and H. Seligman, eds. L'Art de Deschiffrer: Traité de Déchiffrement du XVIIe Siècle de la Secrétairerie d'Etat et de Guerre Espagnole (Belgium: Université de Louvain, 1967.)

36 Ludwig von Rockinger: "Über eine bayerische Sammlung von Schlüsseln zu Geheimschriften des sechzehnten Jahrhunderts," Archivalische Zeitschrift 1892: 21-96; Franz Stix, "Die Geheimschriftenschlüssel der Kabinetskanzlei des Kaiser," Nachrichten von der Gesellschaft der Wissenschaften zu Göttingen, Philologisch-Historische Klasse, Neue Folge, Fachgruppe II, 1936: 207-226, and 1937: 61-70.

37 Liisi Karttunen, "Chiffres diplomatiques des nonces de Pologne vers la fin du XVIe siècle: Extraits des archives des princes Chigi à Rome," Annales Academiae Scientiarum Fennice (Helsinki: 1911).

$3^{8}$ David Kahn, The Codebreakers. The Story of Secret Writing (London: Weidenfeld and Nicolson, 1967); amplified edition: The Codebreakers: The Comprehensive History of Secret Communication from Ancient Times to the Internet (New York: Scribner, 1996).

39 Cryptologia comes out with four issues a year. Taylor and Francis took over publishing it in 2006: http://www.tandfonline.com/toc/ucry2o/current 
professional meetings of the history of cryptology in Maryland, which is organized by the National Security Agency (NSA) of the United States. The National Cryptologic Museum, located near the conference site, bought up Kahn's thematic book collection, thus becoming the most concentrated library on the history of cryptography. ${ }^{40}$ The field has been energized by its journal, conferences and numerous publications, and the source material is so rich that it feeds a steady stream of reviews and monographs. ${ }^{41}$ Among these works Simon Singh's The Code Book has been the most successful among lay readers. ${ }^{42}$

A common feature of these publications, however, is that they focus primarily on the evolution of enciphering and decoding methods, which are rarely contextualized in their wider social environment. Early modern cryptography is researched almost exclusively from two points of view. First, it is well documented how certain authors from the fifteenth to seventeenth centuries (Leon Battista Alberti, Johannes Trithemius, Giambattista Della Porta, Gustavus Selenus, Blaise Vigenère, and John Falconer, etc.) put forward sophisticated methods in their famous summaries on steganography and cryptography. These were complicated intellectual techniques, too complicated in fact for diplomatic, military, or private use by their contemporaries; thus, only limited application of them can be documented until the eighteenth century. Considerably less sophisticated methods were applied in real life: enciphered dispatches, secret letters used in spy communications and conspiracies, and deciphering manuals in early modern Italy, Spain, France, and Germany followed a system that, due to its simplicity, was beneath the expertise of the above-mentioned intellectuals-and this diplomatic application is the second major topic of

40 http://www.cryptologicfoundation.org/; http://www.nsa.gov/about/cryptologic_heritage/ museum/index.shtml.

41 Edmond Lerville, Les Cahiers secrets de la cryptographie (Paris: Rocher, 1972); L. Sacco, Manuel de Cryptographie (Paris: Payot, 1951); Gerhard Strasser, Lingua Universalis: Kryptologie und Theorie der Universalsprachen im 16. und 17. Jahrhundert (Wolfenbütteler Forschungen, Vol. 38.) (Wiesbaden: Harrassowitz, 1988); Fred B. Wrixon, Codes, Ciphers and other Cryptic and Clandestine Communication (New York: Black Dog, 1998); Friedrich L. Bauer, Entzifferte Geheimnisse: Methoden und Maximen der Kryptologie (Berlin: Springer, 2000) English translation: Decrypted Secrets. Methods and Maxims of Cryptology (Berlin: Springer, 2002); Klaus Schmeh, Codeknacker gegen Codemacher: Die faszinierende Geschichte der Verschlüsselung (Dortmund: W3L, 2014); idem, Nicht zu knacken: Von ungelösten Enigma-Codes zu den Briefen des Zodiac-Killers (Hanser, 2012); Craig Bauer, Secret History: The Story of Cryptology (CRC: Chapman Hall, 2013); idem, Unsolved!: The History and Mystery of the World's Greatest Ciphers from Ancient Egypt to Online Secret Societies (Princeton: Princeton University Press, 2017).

42 Simon Singh, The Code Book: The Science of Secrecy from Ancient Egypt to Quantum Cryptography (New York: Doubleday, 1999). 
the secondary literature. Outside the realm of theoretical inventions and their practical use in the diplomatic sphere, cryptography is rarely investigated, even though noblemen, scientists, medical doctors, university professors and students, alchemists, engineers, and "everyday" members of society often used enciphering methods for their own - not necessarily diplomatic - purposes. The wider context of secrecy is rarely mentioned in monographs and articles on cryptography, even though motivations behind everyday use of cryptography can be hardly understood without integrating the application of ciphers in the larger context of secrecy.

The historiography of cryptography as a field is unduly internalist. The internalist historical approach primarily looks for the intellectual content in the history of a science, and documents the birth and growth of such concepts, theories and methods that are the predecessors of the theories and methods presently in use. The so-called externalist approach, by contrast, includes the social, economic and institutional aspects of a given area of science. It investigates the social environment in which a certain technology was used and which often affected scientific content itself. ${ }^{43}$

With the exception of a few articles on specific topics, ${ }^{44}$ general studd ies on the history of cryptography regard encryption as a scientific technology and mostly fail to consider its real life use and its social context. This tendency is vividly exemplified in an influential article by David Kahn from 2008 in which he enumerates the tasks and questions of the field that remain to be solved. He draws attention to a number of basic and so far under-researched topics, but these are mostly connected to the origin and history of certain cryptographic methods, such as the polyalphabetic secret writing or the nomenclature, not the social history of secret writings. ${ }^{45}$

I have argued first that though the phenomenon of secrecy has received considerable socially sensitive attention, this hardly affected secret writings. Second, I pointed out that cryptography is barely integrated into the context of secrecy, and is often portrayed as a technology and as a diplomatic practice, detached from its broader social environment.

43 Steven Shapin, "Discipline and Bounding: The History and Sociology of Science as Seen through the Externalism-Internalism Debate," History of Science 30 (1992), 333-369.

44 A number of case studies can be quoted here, most frequently published in Cryptologia, which do take real life situations into account. Even these, however, focus on the political and diplomatic application of cryptography, and consider issues of secrecy rarely.

45 David Kahn, "The Future of the Past-Questions in Cryptologic History," Cryptologia 32 (2008):56-61. 


\subsection{Cryptography in Hungary}

This lack of attention is even more striking in Hungary, a country which, due to its historic conflicts and dividedness, provided rich soil for the use of ciphers, a fact that the historian Ágnes R. Várkonyi has more than once warned about. ${ }^{46}$ This issue, however, is rather neglected in Hungarian ree search, despite the fact that several valuable initiatives have been made by Hungarian scholars.

An early example is Ágoston Ötvös' 1848 publication, a highly representative selection from the encrypted correspondence of the era of György Rákóczi I, Prince of Transylvania (prince: 1630-1648). Ötvös, originally a physician, found the letters in the rich collection of the Batthyány library in Gyulafehérvár (Alba Iulia, today Romania), and by all appearances it was he himself who had deciphered the enciphered letters, and who had reconstructed at least six different codes. ${ }^{47}$

Not counting a few sporadic source publications, there was a long pause in the historiography of Hungarian cryptography following Ötvös, until 1970 when lieutenant colonel Zoltán Révay became interested in the field, supposedly as a result of his military intelligence position. First he published a general monograph ${ }^{48}$ then a reference book describing the ciphers that survived from the freedom fight of Ferenc Rákóczi II (1703-1711). ${ }^{49}$

Révay's monograph is rather confusing. On the one hand, it must be praised for being the first Hungarian report on the post WWII developments of decoding, based partly on David Kahn's Codebreakers, partly on the personal experience of the author. In addition, the author compiled a useful list of the relevant publications related to the history of cryptography in Hungary, and he described a number of hand-written sources from diverse archives and manuscript collections for the first time. On the other hand, the work displays certain typical shortages of the amateur historian:

46 Ágnes R. Várkonyi, "A tájékoztatás hatalma” (The power of information), in Információáramlás a magyar és török végvári rendszerben (Information flow in the Hungarian and Turkish military zones), ed. Petercsák Tivadar and Berecz Mátyás (Eger: Dobó István Vármúzeum, 1999), 9-32, particularly: 17 .

47 Ágoston Ötvös, Rejtelmes levelek első Rákóczy György korából (Secret letters from the time of Rákóczi György I), (Kolozsvár, 1848).

48 Révay Zoltán, Titkosírások. Fejezetek a rejtjelezés történetéböl (Secret Writings: Chapters from the History of Cryptography) (Budapest, Zrínyi Katonai Kiadó, 1978.)

49 Révay Zoltán, II. Rákóczi Ferenc és korának rejtjelezése (XVIII. század) (Cryptography of Ferenc Rákóczi II and his Age) (Budapest: Magyar Néphadsereg Híradó Főnökség Kiadása, 1974). 
haphazard references, misunderstood sources, including a horoscope depicting astrological symbols, mistakenly labeled as the earliest Hungarian example of secret writing. ${ }^{50}$ More importantly, Révay touches on plagiaa rism when introducing the findings of Ötvös. He does cite his source, but at one point forgets to mention that the messages were decoded by the nineteenth-century physician-historian, ${ }^{51}$ and in several places he explice itly claims to be the decoder..$^{2}$ And, as if that was not enough, he paints a distorted picture of the process of deciphering. He gives a detailed description of his own decoding process, but what he describes is in effect the typical case of backwards reasoning relying on the knowledge of the solution, a procedure that is really hard to follow when one does not happen to have the key. ${ }^{53}$ Despite all of these contradictions, the book is a good starting point for anyone wishing to study early modern cryptography in Hungary. Révay's second book, Cryptography of Ferenc Rákóczi II and his Age, is a remarkably useful source analysis. It presents and analyzes one by one those nearly seventy cipher tables that survived from the freedom fight of Rákóczi. This is a groundbreaking work despite the fact that Révay had worked from the nineteenth-century copies of the Hungarian Academy of Sciences, ${ }^{54}$ not the original sources held in the National Archives of Hungary. ${ }^{55}$

Interestingly enough, the other important achievement of the seventies is also connected to a lieutenant colonel of the Hungarian national army, Ottó Gyürk. Parallel with Gábor Gilicze, then a university student, he found how to break the cipher system of the secret diary of the writer Géza Gárdonyi (1863-1922). ${ }^{56}$ Subsequently, he started to work on a statistical analysis of the mysterious Rohonc codex held in the archives of the Library of the Hungarian Academy of Sciences. This second manuscript, however, resisted his decoding efforts. ${ }^{57}$

During the following decades of Hungarian historiography, ciphers of Prince György Rákóczi, of the Wesselényi movement and of Prince Ferenc Rákóczi were mentioned several times (most often in the studies of Ágnes

52 Révay, Titkosírások, 81.

53 Révay, Titkosírások, 95.

54 Hungarian Academy of Sciences, Manuscript Collection, Ms 4951/5.

55 MNL OL G 15 , Caps. C. Fasc 43-44

56 Gyürk Ottó, "Hogyan fejtettem meg Gárdonyi titkosírását?" Élet és Tudomány 24/47 (1969): 2211-2216; Gárdonyi Géza, Titkosnapló (Secret diary) (Budapest: Szépirodalmi Kiadó, 1974.) 57 Gyürk Ottó, "Megfejthető-e a Rohonci-kódex?" (Is the Rohonc codex decipherable?) Élet és Tudomány 25 (1970), 1923-1924. 
R. Várkonyi), ${ }^{58}$ but they hardly ever stood in the spotlight. One of these studies will be brought up more than once here: the correspondence of Archbishop Péter Pázmány and C. H. Motmann, his source of information from Rome. This extremely complex code was reconstructed by the historian Péter Tusor, and the analyst Imre Máté, retired head of the National Cipher Council. ${ }^{59}$ Tusor and Máté achieved this result through using historf ical reasoning and mathematical analysis in a parallel way.

Among contemporary research, one may cite the code-breaking results of István Vadai and Hanna Vámos, they managed to decipher dozens of enciphered letters from the $17^{\text {th }}$ century. ${ }^{60}$ Somewhat beyond our period, Hanna Vámos has also come out with the reconstruction of the polyalphabetic code of the Nagybajom manuscript. ${ }^{61}$ These results nicely illustrate the rich potential involved in historical codebreaking.

Finally, I would like to mention my own monograph on the Rohonc codex $^{6_{2}}$ a manuscript that has long been regarded with suspicion. As a result of the decryption of Levente Zoltán Király and Gábor Tokai, this 450-page prayer-book will also be available. ${ }^{63}$ Though kept in the Library of the Hungarian Academy of Sciences, it is not evident that this (most

58 Ágnes R. Várkonyi, A rejtőzködő murányi Vénusz (The hiding Venus of Murany) (Budapest: Helikon Könyvkiadó, 1987), 213-15; eadem, “Az elveszett idő: Zrínyi Miklós nádori emlékirata?" (The time lost: a memorandum of Palatine Miklós Zrínyi?) Hadtörténeti Közlemények 113 (2000): 269-328, esp. 291; eadem, “A tájékoztatás hatalma."

59 Péter Tusor, "Pázmány bíboros olasz rejtjelkulcsa: C. H. Motmann 'Residente d'Ungheria': A római magyar agenzia történetéhez" (Cardinal Pázmány's Italian Codebook: C. H. Motmann 'Residente d'Ungheria,' On the History of the Hungarian Agenzia in Rome), Hadtörténelmi közlemények 116 (2003): 535-81;

6 o Hanna Vámos, István Vadai, "Pázmány Péter és I. Rákóczy György titkosírása" (The cipher of Péter Pázmány and György Rákóczi I), in Alinka Ajkay and Rita Bajáki eds. Pázmány nyomában (Following Pázmány) (Vác: Mondat, 2013), 461-479; eidem, Kuruc titkosírások megfejtése (Solutions of Kuruc ciphers), in István Mercs, ed. Kuruc(kodó) irodalom (Kuruc(izing) literature) (Nyíregyháza: Móricz Zsigmond Kulturális Egyesület, 2013), 209-221; István Vadai, "Titkosírás" (Cryptography) in Magyar Müvelődéstörténeti Lexikon (Encyclopaedia of Hungarian cultural history), vol. 12, ed. Péter Kőszeghy Péter and Zsuzsanna Tamás (Budapest, Balassi, 2011), 6o-65; idem, "Két XVII. századi titkosírás megfejtése" (Solution to two seventeenth-century ciphers) in Pálffy Kata leveleskönyve: Iratok Illésházy István bujdosásának történetéhez (1602-1606) (Letterbook of Kata Pálfyy: Texts relevant for István Illésházy's exile), ed. Ötvös Péter (Szeged: Scriptum $\mathrm{Kft}, 1991), 183-89$.

61 Hanna Vámos, "Leleplezett titok: Pálóczi Horváth Ádám titkos, szabadkőműves dokumentuma," (Unrevealed secret: the Freemason document of Ádám Pálóczi Horváth) in István Csörsz Rumen and Béla Hegedüs, eds., Magyar Arión (Hungarian Arion) (Budapest: rec.iti, 2011), http://rec.iti.mta.hu/rec.iti

62 Benedek Láng, A rohonci kód (the Rohonc code) (Budapest: Jaffa, 2011); idem, The Rohonc Code: Tracing a Historical Riddle, forthcoming.

63 The publication of Gábor Tokai and Levente Zoltán Király is forthcoming. 
certainly) sixteenth-century codex is related to Hungarian history. It is not likely either that we deal with a real cipher here, the context of constructed languages seems more probable. In my monograph, I give a historiographical overview of fascinating and occasionally almost ludicrous theories associated with the Codex and discuss the possible interpretations of the manuscript: as a Biblical commentary, as an apocryphal gospel, as a secret book written for and by a sect. I also provide an overview of the secret writing systems known in the early modern times, and an account of numerous efforts to create an artificial language or to find a long-lost perfect language, as both endeavors were especially popular at the time the Codex was most probably made. The book tests a number of codebreaking methods in order to decipher the codex and finally presents a solution (the solution of Király and Tokai) to the enigma of its content.

To sum up: there are useful case studies available on the cryptographic practice of the region, but neither a systematic summary, nor a socially oriented overview has been published. It is high time the social history of the secret writings of the Carpathian basin was researched. 